\title{
Evaluation of some water saving devices in urban areas: A case study from the Sultanate of Oman
}

$$
\begin{aligned}
& \text { تقييم بعض أجهزة توفير المياه في المناطق الحضرية: دراسة حالة من سلطنة عمان } \\
& \text { حيدر عبد الرحمن"1 وحليمة الفارسي2 ومشتاق أحمد } 1 \text { وماثيوس غوسن } 3
\end{aligned}
$$

Abstract. Water Saving Devices (WSDs) sustain demands for potable water, soften impacts on supply systems and inflict a positive effect on wastewater treatment systems. This study evaluated the effect of some WSDs in Oman. A questionnaire survey and some case studies were used. The survey results revealed that the pipe line system network for water supply accounted for about $67.7 \%$, whereas the rest mainly use tankers. Around $37.2 \%$ of the participants received consumed 25000 - 45000 liters per household per month. Case studies showed no significant difference in household water usage before and after installation of WSDs due to pre-installed aerators. Toilet bags and dual flush toilets were not effective promoting users to flush. However, WSDs were significantly effective in restaurants, mosques, hotels and government buildings. Water consumption in shopping centres and hospitals slightly decreased. Retrofitting programs that involve replacement of existing plumbing equipment and residential water audit programs are recommended.

KEYwORDS: Urban water; water saving devices; domestic water conservation.

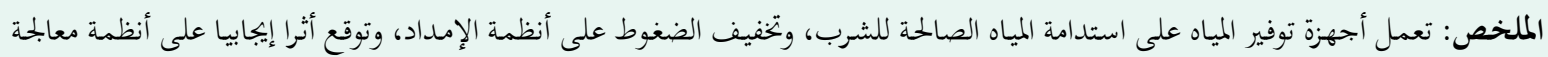

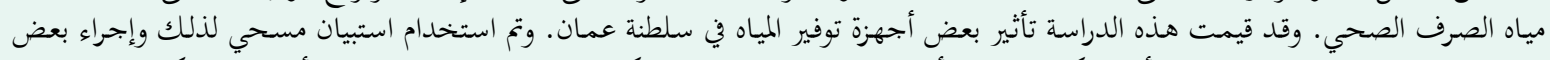

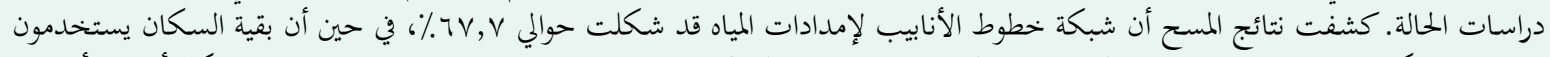

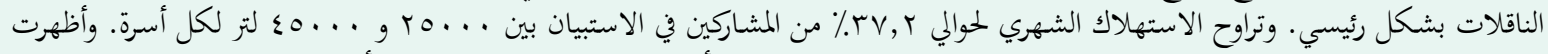

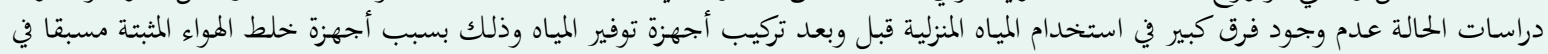

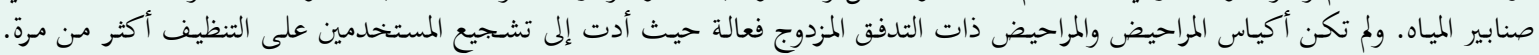

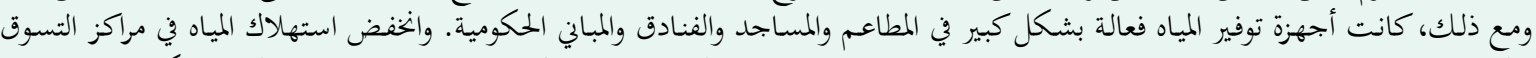

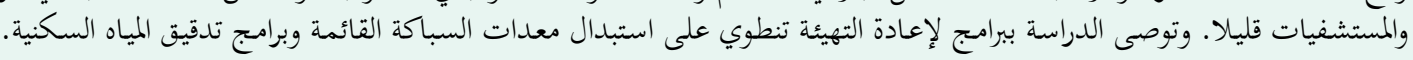

$$
\begin{aligned}
& \text { الكلمات المفتاحية: المياه في المناطق الحضرية، أجهزة توفير المياه، الحفاظ على المياه المنزلية }
\end{aligned}
$$

\section{Introduction}

$\mathrm{T}$ he mean annual rainfall throughout most of Oman is less than $100 \mathrm{~mm}$ with marked regional variations in local rainfall amounts. The available water resources of the Sultanate are estimated at 1267 $\mathrm{Mm}^{3}$ (Million cubic meters) and the water demand is about $1645 \mathrm{Mm}^{3}$, resulting in an annual water deficit of $378 \mathrm{Mm}^{3}$. (MRMWR, 2008). The per capita water consumption is reported as 200 liters/day. In some areas, particularly the coastal regions, water abstractions has largely exceeded the rate of groundwater recharge, which lead to continuous lowering of the water table and sea water intrusion (Al-Ajmi and Abdel Rahman, 2001).

*1 Hayder Abdel Rahman ( Sultan Qaboos University, College of Agricultural and Marine Sciences, Department of Soils, Water and Agricultural Engineering, Box 34, Al-Khod 123. Sultanate of Oman. email: hayderar@squ.edu.om.

2 Ministry of Regional Municipalities and Water Resources, Muscat, Sultanate of Oman

3 Office of Research and Graduate Studies, Alfaisal University, Riyadh, Saudi Arabia.
Saving in domestic water is sought as part of an integrated conservation/augmentation plan. Domestic water is more expensive compared to agricultural and industrial water. Domestic water in the Muscat Governorate (Capital area) comes mainly from desalination plants that cost 0.5 OMR (\$1.3) per cubic meter to produce and is subsidized by the government and distributed to the public at the rate of 0.44 OMR (\$1.14) including transport costs (MHEW, 2002). The total daily volume of desalinated water produced for domestic purposes in the Capital was 221,260 $\mathrm{m}^{3} /$ day generated from $6 \mathrm{de}$ salination plants. The maximum daily demand for water in the region was estimated at $233,000 \mathrm{~m}^{3}$ /day and was recorded in October while the minimum daily demand stood at 148,000 $\mathrm{m}^{3}$ /day reported in February.

The average household water use worldwide varies from 190 to 285 liters per person per day and breaks down as $42 \%$ for toilet use, $32 \%$ for bathing, $14 \%$ for laundry, $8 \%$ for kitchen and $4 \%$ for cooking purposes. Plumbing retrofit programs have been recognized as the quickest and simplest way to reduce demand for potable water and soften the impact such demand places on a 
water supply system (Al-Rumikhani. 2000).

Lallana et al. (2001) reported that Aerators (taps with air devices) and taps with thermostats could save up to $50 \%$ water whereas those equipped with infrared sensors could save up to $80 \%$. Devices that limit shower flow could inflict a $10-40 \%$ water savings. Toilets are the biggest water-guzzling appliances in homes (13-16 liters per flush). Water saving devices in this respect fall into five categories (García and Cortés, 1989): Low flush toilets using smaller tanks and a specially designed bowl to give the same flush power but with less water, toilets using displacement technologies such as a plastic container that can be filled with water and placed in a toilet tank to reduce the amount of water used per flush, vacuum and waterless toilets, and toilet cycle diverters that diverts water to the tank and less to the toilet bowl. Water saving showerheads includes thermostatic mixers with a calibrated dial, allowing the temperature to be set from experience, and showerheads that create finer drops. Different forms of water saving taps exist: faucet aerators that break the flowing water into fine droplets and taps with sensors and push back device taps with pressure reduction-flow regulators; and commercial "power-spray" washers with vigorous spray patterns. Urinals can save water compared with toilets, but will waste a considerable amount of water if incorrectly installed. Typically, urinals account for about 20 percent of office water use, but this figure can vary a good deal. Urinals that use no water, other than for daily cleaning, are now widely available.

More than 4.8 billion gallons of water are flushed down toilets each day in the United States (Jensen, 1991). The most important source of saving is in toilet replacement or modification which gives more than $61 \%$ of water saving, but it costs more than the other devices. Toilet dams, which hold back a reservoir of water when the toilet is flushed, can also be used instead of plastic container to save water. Two anti-slip ribs at both ends insure dams remain in place when installed. The dams also have a high saving percentage of $51 \%$. There is a great potential to reduce water consumption by installing low-flush toilets in new construction and building rehabilitation or remodelling. Effective January 1, 1994, the Energy Policy Act of 1992 (Public Law 102-486) required that all new toilets produced for home use must operate on 6 liters per flush or less. Toilets that operate on 13 liters per flush were continued to be manufactured, but their use was to be limited to certain commercial applications effective January l, 1997.

In Mexico, efforts have been made to improve the water use efficiency of traditional toilets by placing containers, bricks, bags filled with water or plastic compartments in the tank to reduce its capacity (García and Cortés, 1990). Most of these methods, however, reduce the toilet's siphoning effect. According to tests carried out by the Mexican Institute of Water Technology (García and Cortés, 1991) a viable option for saving water in these fixtures is to lengthen the discharge siphon, which reduces water consumption. Showers take second place in water demand at home in Mexico City and regulations specify that the discharge from showers should not exceed $10 \mathrm{~L} / \mathrm{min}$. This can be accomplished by using new shower-head designs or flow reducers. Flow reduction in basin and sink faucets is achieved by using aerators, which add air to the stream and disperse it, increasing the spread and therefore the washing efficiency. Another option that has been explored, with excellent results, is the installation of valves or sensors that activate the water flow only when the hands are placed beneath them. A study carried out by the IMTA showed that a basin faucet equipped with a sensor discharged $1.5 \mathrm{~L} / \mathrm{min}$ at a pressure of $0.2 \mathrm{~kg} / \mathrm{cm}^{2}$ and $5.9 \mathrm{~L} / \mathrm{min}$ at a pressure of $2.5 \mathrm{~kg} / \mathrm{cm}^{2}$ (García and Cortés, 1989). Savings in washing machines are achieved by loading them with the appropriate weight of clothes, using the water levels necessary for efficient operation, or using washers that require less water. There are basically two types of washing machines: front loaders and tub machines (top loaders); the first type can use up to half the amount of water $-50 \%$ of the hot water and $33 \%$ of the detergent - required by the second type. The manufacture of efficient washing machines has reduced water consumption by up to $24 \%$ in comparison with traditional models. The volume of water used by dish washers varies between 49 and 95 liters per day. However, more efficient models have been introduced that require only 36 to 45 liters per day.

In Oman, in a study that was implemented in 1998 under the auspices of the Ministry of Regional Municipalities, Environment and Water Resources (MRMEWR), WSDs were installed in the Ministry building in Ruwi (MWR,1998). The main objectives were to assess WSDs performance, percentage of water savings, water users' responses and feedback. The experiment duration was from $1 / 6 / 1993$ until 1/12/1996. On average the number of employees before installing WSDs was 186 and after installing were 209. Water bills before and after installation was compared and analyzed. The highest monthly consumption before installation was in July with an average rate of 313.24 liters per person and with the lowest monthly consumption in February with average consumption rate of 181.35 liters per person. Whereas after installation, the highest monthly consumption was in September with average rate of 247 liters per person and with the lowest monthly consumption in February with a average consumption rate of 133.21 liters per person. The average monthly consumption before installing was 236.27 liters per person and after installation it came down to 205.59 liters per person. The net average water saving per month was 30.68 liters per person with a saving percentage of $13 \%$. Considering an average number of employees of 209 , the total water consumption was 49380.4 liters/month. Thus, the total monthly water savings was 6420 liters which is equivalent to total annual 
water saving of 77033 liters. By multiplying the cost of one liter (0.44 Beiza) by the total water savings 77033 liters; the total annual financial saving was $34 \mathrm{OMR}$ and 170 OMR for the whole life span of the devices 5 years. The feedback from the questionnaire indicated that $17 \%$ of the water users knew that WSDs were installed and $83 \%$ of the water users did not have any problems or annoyed while using retrofitted aerators tabs (MWR, 2000).

\section{Materials and methods}

A questionnaire was designed to test public attitudes towards the water saving devices, knowledge about water shortage in the Sultanate and willingness to install water saving devices, and other related information. About 125 questionnaires were distributed through students from Sultan Qaboos University to university students, colleagues, friends, neighbors and others so that it can be explained to them if there were any ambiguities or misunderstandings.

The second part of the study was supported by the Ministry of Regional Municipalities and Water Resources (MRMWR). The work was carried out by introducing the WSDs at pilot sites, which were selected with direct guidance and supervision from MRMEWR, of some voluntaries who accepted the installation of WSDs. Sites selected, were from government buildings, public houses and commercials buildings. Readings were taken on a daily basis at the same time.

The pilot sites reported here were two private villas, one hotel, one restaurant, one government building, one mosque, and one commercial building. Water meters for the sites with defective meters were first replaced. Automated data loggers for continuous loggings were then installed in the seven sites namely two villas in Ghobrah, Muscat City Centre, Al Araimi Mosque, the Grill House restaurant, Holliday Inn Hotel and the Ministry of Regional Municipalities and Water Resources' building. Monitoring commenced for three months after installation of WSDs.

All owners agreed to cooperate in the study. In return for their cooperation they received a variable-load washing machine, which presumably would serve the purposes of the study. Different types of WSDs were installed including aerators, toilet bags or dual flush toilets, lowflow shower heads and variable-load washing machines. For all sites the mean water consumption before installation of WSDs was compared against mean water consumption after installation of WSDs using t-Test comparison of means for data sets with unequal numbers. Significance factor was taken as $95 \%$.

\section{Results and discussion}

\section{Questionnaire}

The questionnaire results were analyzed using the Statistical Program for Social Science (SPSS). The questionnaires were distributed among various categories of participants. Participants (60\% males) with a high level of education (university) represented $56.5 \%$, whereas those with medium and low levels of education constituted 29 and $14.5 \%$ respectively; $79 \%$ of the participants being in the age group of $20-40$ years. Most of the participants were government employees (71.4\%) with housewives representing only $6.7 \%$. Thirty five per cent of the participants earned an income of $\$ 1,000-15,000$ per month whereas $47 \%$ and $18 \%$ drew monthly incomes less than $\$ 500$ and more than $\$ 1,500$ respectively. The majority of the participants (40.3\%) had a family size of 3-5 persons, whereas family size of 1-2 persons per family represented the lowest percentage (6.7\%)

Pipe line network system as a water source at home accounted for $67.7 \%$ in the study, whereas those who transported water through tankers to their homes accounted for $21 \%$, while those who used a mixture of tankers and the pipeline accounted for $6.5 \%$ and others (e.g. own well) accounted for $4.8 \%$. It was indicated from the water bills paid that $37.2 \%$ of the participants used 25,000 - 45,000 liters per month per household where as $12.4 \%$ used less than 10,000 liters and $21.5 \%$ used more than 45,000 liters per month per household. The pattern of water use at home during bath using the shower accounted for $86.1 \%$ and those who were filling the bath tub accounted for $13.9 \%$. Whereas $78.9 \%$ of the participants kept the tap running intermittently when shaving and brushing, $21.1 \%$ kept the tap running continuously. In ranking house compartments, $31.7 \%$ said that the kitchen and the bathroom used the most amount of water, where as $19.5 \%$ attributed this to the washing machine and $17.1 \%$ said that irrigating gardens and plants used the most.

About $78 \%$ of the participants were not using any water saving methods at their homes and yet, $76 \%$ of the participants considered themselves as water savers. Different types of water saving devices were employed by those using WSDs and almost 30\% of them utilized sensors in their taps whereas $18 \%$ applied either push types or a combination.

The survey revealed a high awareness (88\%) about the water problem of the country. About $14 \%$ of the participants felt that installing WSDs at homes wouldn't make any difference; $86 \%$ felt that the effects would be moderate to significant and $70 \%$ were willing to install the water saving devices in their houses. Yet $92 \%$ of those surveyed expected to benefit from using water saving devices in term of money and help solving water shortage problems of the country, with a significant positive correlation at the 0.01 level between the willingness of 
the participant to install the water saving devices and to buy those devices. About $86 \%$ of the participants felt that there was a significant relationship between water consumption and social status of water user, which means that as income increases water consumption increases because of the lifestyle changes and water consuming facilities found such as gardens, swimming pools, and washing machines.

There was a significant correlation between the monthly income of the participants and their average water bill per month, while no correlation existed between the size of the family and the average water bill per month and this was attributed to the size of the house, presence of a cultivated area (garden), age of the kids and living habits.

\section{Case Studies}

\subsection{Private Villas}

Table 1 shows the average weekly water consumption of the two villas reported in this study as deducted from the billing authority (Oman Investment and Finance Company). Villa I had eleven occupants, seven of whom were children under 18, whereas Villa 2 had seven occupants three of whom were children. Seven aerators, 5 toilet bags, 4 low-flow showerheads, 2 sensor activated taps and one variable-load washing machine were installed in Villa 1, whereas an extra aerator was installed in Villa 2. Comparison of water consumption data, to detect any increase or decrease in water consumption was performed by using the adjustment factors for water consumption which were calculated as a deviation from the average weekly value for water consumption. Weekly
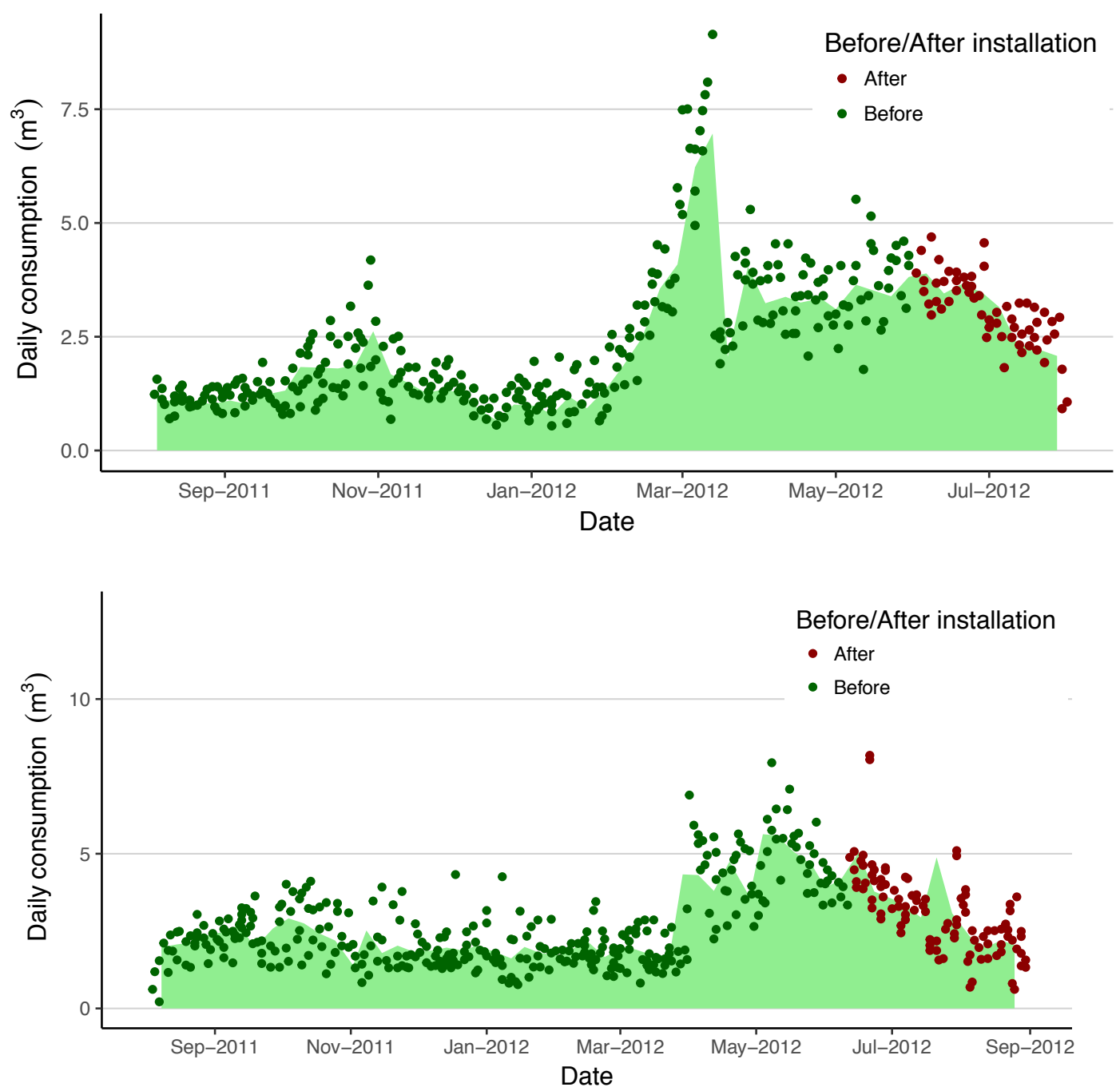

Figure 1. Daily water consumption in Villa 1 (top) and Villa 2 (bottom) before and after installation of water saving devices (WSDs). The weekly average $\left(\mathrm{m}^{-3} \cdot \mathrm{d}^{-1}\right)$ is presented in the background. 
Table 1. Weekly water consumption $\left(\mathrm{m}^{3}\right)$ and adjustment factors for the two Villas.

\begin{tabular}{|c|c|c|c|c|}
\hline Month & $\begin{array}{c}\text { Villa I } \\
\text { Consumption }\end{array}$ & $\begin{array}{c}\text { Villa } 2 \\
\text { Adj. Factor }\end{array}$ & Consumption & Adj. Factor \\
\hline January & 11.97 & 0.73 & 16.26 & 0.87 \\
\hline February & 16.75 & 1.02 & 17.75 & 0.95 \\
\hline March & 24.16 & 1.47 & 13.77 & 0.74 \\
\hline April & 22.17 & 1.35 & 27.07 & 1.45 \\
\hline May & 21.90 & 1.33 & 24.61 & 1.32 \\
\hline June & 20.32 & 1.23 & 21.00 & 1.13 \\
\hline July & 17.61 & 1.07 & 20.55 & 1.10 \\
\hline August & 9.80 & 0.60 & 14.45 & 0.77 \\
\hline September & 11.74 & 0.71 & 17.27 & 0.93 \\
\hline October & 17.03 & 1.03 & 19.19 & 1.03 \\
\hline November & 12.19 & 0.74 & 15.63 & 0.84 \\
\hline December & 11.97 & 0.73 & 16.26 & 0.87 \\
\hline Total & 197.62 & & 223.81 & \\
\hline Average & 16.47 & & 18.65 & \\
\hline St. deviation & 4.89 & & 4.05 & \\
\hline
\end{tabular}

water consumption data were then adjusted for seasonal variations using these factors, in the absence of ample water consumption data to properly account for seasonality and the variable nature of water consumption. A comparison between weekly figures before and after installation of WSDs was performed using a one-tailed t-test with a significance level of $95 \%$.

No apparent significant differences in water consumption before and after installation of WSDs were detected for both villas, as can be seen from (Fig. 1) and table 2 . The average daily water consumption decreased from 2.40 to $2.28 \mathrm{~m}^{3}$ in Villa 1, but increased from 2.66 to $3.23 \mathrm{~m}^{3}$ in Villa 2 . This was attributed to the fact that faucets in houses were already equipped with aerators, so no significant water savings were detected by installing new aerators. Toilet bags and dual flush toilets were not effective and prompted users to flush twice. Lowflow showerheads were probably effective but their effect was masked by the negative effect of other WSDs.

Water consumption varied mostly depending on whether or not an outdoor water use existed. The average water use per inhabitant for the two villas was 180 - $260 \mathrm{~L} /$ day and $350-470 \mathrm{~L} /$ day respectively. The higher value was due mainly to the use of the garden water. These figures compare well with those in neighboring Gulf Cooperation Council countries (GCC).

\subsection{Muscat City Centre}

Muscat City Centre is the largest shopping centre in Oman. Water use varies according to the day of the week and the shopping season. Occupancy of the centre is difficult to quantify as there are no checks on people entering the structure. For this reason, the only reliable information was obtained through historic water meter data.

It is worthy to note that the number of people entering City Centre is quite large. The average water consumption per person is on the order of 5-10 liters per day considering that not all customers use toilets or ablution rooms. As such, on average over 10,000 people enter the centre for diverse purposes on a daily basis. The daily water consumption on week days was slightly more after installation of WSDs $\left(216.66 \mathrm{~m}^{3}\right)$ compared to that before $\left(199.65 \mathrm{~m}^{3}\right)$, while on weekends the average daily use was $220.23 \mathrm{~m}^{3}$ before and $206.32 \mathrm{~m}^{3}$ after as shown. Although this slight difference might be due to seasonal effects, it is probably due to that customers on weekends use ablution rooms more frequently than during weekdays and hence the savings in weekends and their absence during weekdays. The mean weekly consumption decreased from $1,682 \mathrm{~m}^{3}$ to $1,496 \mathrm{~m}^{3}$ before and after installation of WSDs respectively. To determine whether this difference is significant or not, a t-Test was conducted. Although mean water consumption after installation of WSDs was lower by $185.77 \mathrm{~m}^{3}$, the calculated t value ( $t$-Stat) of 0.95 was lower than critical value ( $\mathrm{t}$-Critical one tail) of 1.30 . This indicates no significant water savings after installation of WSDs at 95\% confidence level. It seems that the combination of toilet bags and self-closing taps, which were installed in City Centre, were not significantly effective in reducing water consumption and people tend to flush the toilets twice and keep pressing on taps to keep the water running.

\subsection{Al-Araimi Mosque}

$\mathrm{Al}$ Araimi mosque is a new and relatively small mosque with 8 toilets and 28 faucets for ablution, all of which 
Table 2. Comparision of daily water consumption before and after installing water saving devices. Significance (Sign.) is based on a one-tail t-test with $\alpha=0.05$.

\begin{tabular}{|c|c|c|c|c|}
\hline \multirow[t]{2}{*}{ Location } & \multirow[t]{2}{*}{$\begin{array}{c}\text { Water Saving } \\
\text { Measures }\end{array}$} & \multicolumn{2}{|c|}{$\begin{array}{l}\text { Water Use } \\
\quad\left(\mathrm{m}^{3} \cdot \mathrm{d}^{-1}\right)\end{array}$} & \multirow[b]{2}{*}{ Sign. } \\
\hline & & Before & After & \\
\hline Villa 1 & $\begin{array}{l}\text { Aerators, Toilet bag, } \\
\text { Low-flow Shower- } \\
\text { head, Sensor acti- } \\
\text { vated taps, Variable } \\
\text { load washing ma- } \\
\text { chine }\end{array}$ & 2.40 & 2.28 & N.S. \\
\hline Villa 2 & $\begin{array}{l}\text { Aerators, Toi- } \\
\text { let Bag, Low-flow } \\
\text { Showerhead, Sensor } \\
\text { activated taps, Vari- } \\
\text { able load washing } \\
\text { machine }\end{array}$ & 2.66 & 3.23 & NS \\
\hline $\begin{array}{r}\text { Muscat } \\
\text { City } \\
\text { Centre }\end{array}$ & $\begin{array}{l}\text { Toilet bags, } \\
\text { Self-closing taps }\end{array}$ & 240.2 & 213.7 & $*$ \\
\hline $\begin{array}{l}\text { Al Araimi } \\
\text { Mosque }\end{array}$ & $\begin{array}{l}\text { Toilet bags, } \\
\text { Self-closing taps }\end{array}$ & 0.22 & 0.13 & $*$ \\
\hline $\begin{array}{r}\text { Grill } \\
\text { House } \\
\text { Restaurant }\end{array}$ & $\begin{array}{l}\text { Dual flush toilets, } \\
\text { Self-closing taps }\end{array}$ & 12.83 & 7.16 & $*$ \\
\hline $\begin{array}{l}\text { Hotel Hol- } \\
\text { iday Inn }\end{array}$ & $\begin{array}{l}\text { Low-flow shower- } \\
\text { heads }\end{array}$ & 101.7 & 90.5 & $*$ \\
\hline $\begin{array}{r}\text { Ministry } \\
\text { (MRME- } \\
\text { WR) } \\
\text { Building }\end{array}$ & $\begin{array}{l}\text { Aerators, Sen- } \\
\text { sor-activated taps, } \\
\text { toilet bags }\end{array}$ & 1.76 & 0.89 & $*$ \\
\hline
\end{tabular}

were fitted with toilet bags and self-closing taps, respectively. Collected data before and after the installation of WSDs is illustrated in (Fig. 2) and (Table 2).

The average weekly water consumption decreased following installation of WSDs by $41 \%$; from $1.58 \mathrm{~m}^{3}$ to $0.93 \mathrm{~m}^{3}$. The calculated $\mathrm{t}$ value (t-Stat) of 6.62 was larger than critical value ( $t$-Critical one tail) of 1.70. Consequently, water consumption decreased significantly following installation of WSDs.

The comparison of these results with those of City Centre, where similar WSDs were installed, reveals the effect of individual WSDs. In Al Araimi Mosque, the ratio of toilet bags to self-closing taps is $8: 28$ whilst in Muscat City Centre it is 52:70. As visitors to shopping Centres use toilets more than those going to the mosque, it could be safely asserted that self-closing taps are far more effective in reducing water consumption.

\subsection{The Grill House Restaurant}

In the Grill House restaurant occupancy was comparable during weekdays and during weekends. The restaurant itself has four toilets and five wash basins. The former was equipped with dual flush toilets while the latter was equipped with self-closing taps. Again seasonality effect was visible in the data illustrated in (Fig. 3) and (Table 2).

Calculated means indicated that the mean weakly use was $89.83 \mathrm{~m}^{3}$ and $50.14 \mathrm{~m}^{3}$ before and after the installation of WSDs respectively, with a $44 \%$ decrease in water consumption following installation of WSDs. This decrease is significant as determined from the results of the t-test. The calculated t-value of 6.67 was larger than critical value (t-Critical one tail) of 1.68. Consequently, water consumption decreased significantly following in-

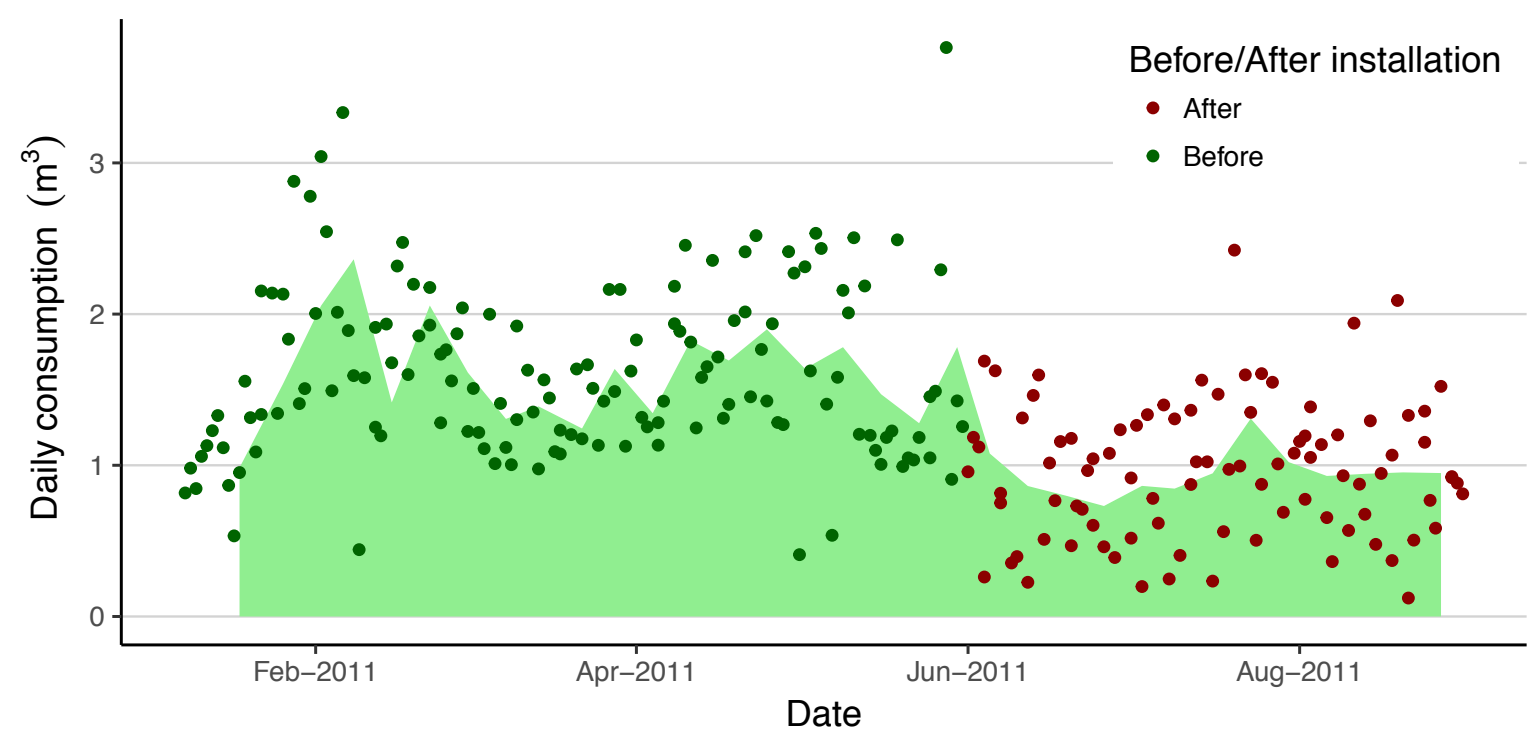

Figure 2. Daily water consumption in Al-Araimi Mosque before and after installation of water saving devices (WSDs). The weekly average $\left(\mathrm{m}^{3} \cdot \mathrm{d}^{-1}\right)$ is presented in the background. 


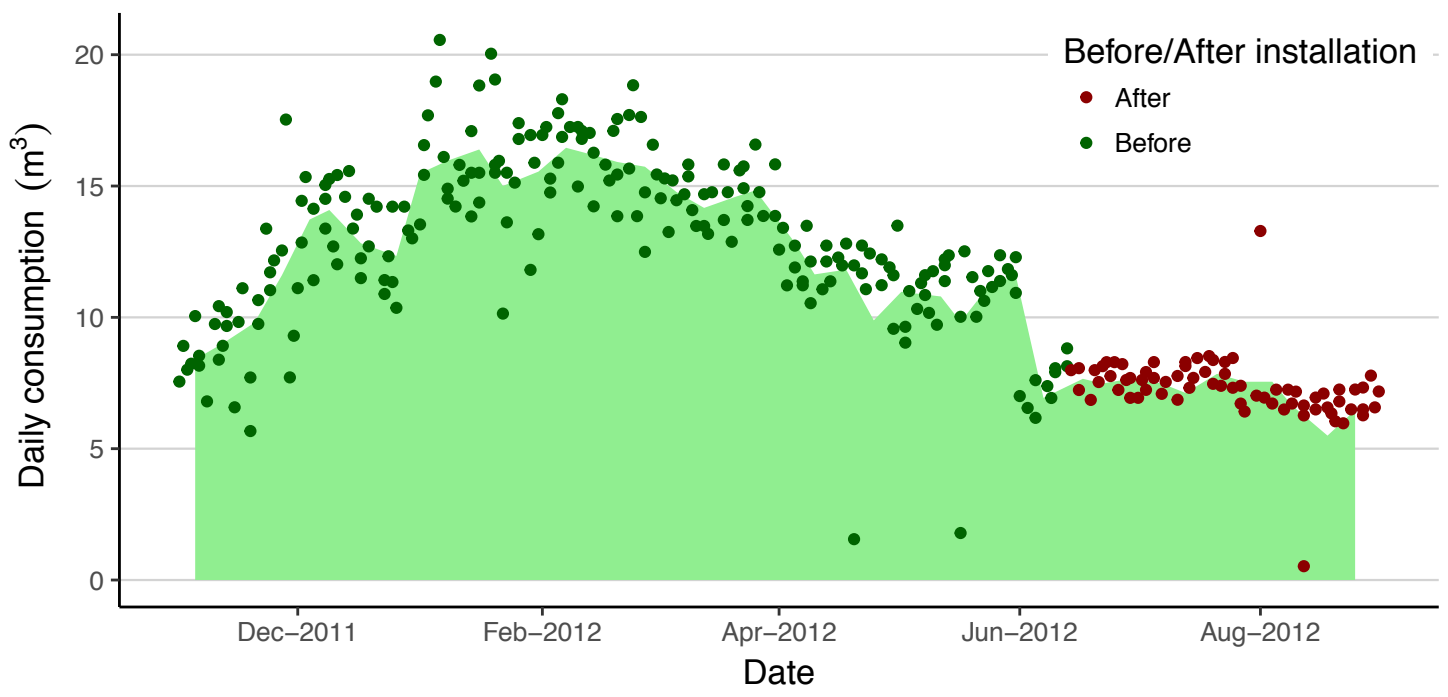

Figure 3. Daily water consumption in Grill House Restaurant before and after installation of water saving devices (WSDs). The weekly average is presented in the background.

stallation of WSDs. This is a further confirmation that self-closing taps are effective in reducing water consumption and a further insight that dual flush toilets might have some effect on reduction of water consumption as well.

\subsection{Holiday Inn Hotel}

Holiday Inn Hotel in Al Khuwair has 123 rooms in total. There are two restaurants, a small gymnasium and a swimming pool. All toilets are operating on a half -flush cycle. Water consumption before and after installation of WSD is illustrated by (Fig. 4) and (Table 2). Descriptive statistics showed that the mean weekly consump- tion before installation was $711.98 \mathrm{~m}^{3}$ and decreased to $633.47 \mathrm{~m}^{3}$ after the installation of the WSDs. The calculated $t$ value of 1.71 was larger than critical value ( $t$-Critical one tail) of 1.67 , consequently water consumption decreased significantly following installation of WSDs. As indicated in table 2, water consumption decreased significantly over that consumption prior to installation of WSDs. The effect of individual devices could not be isolated in that which device is more effective in saving water. However, in view of the volume of water applied, it is thought that low-flow showerheads might have had an effect.

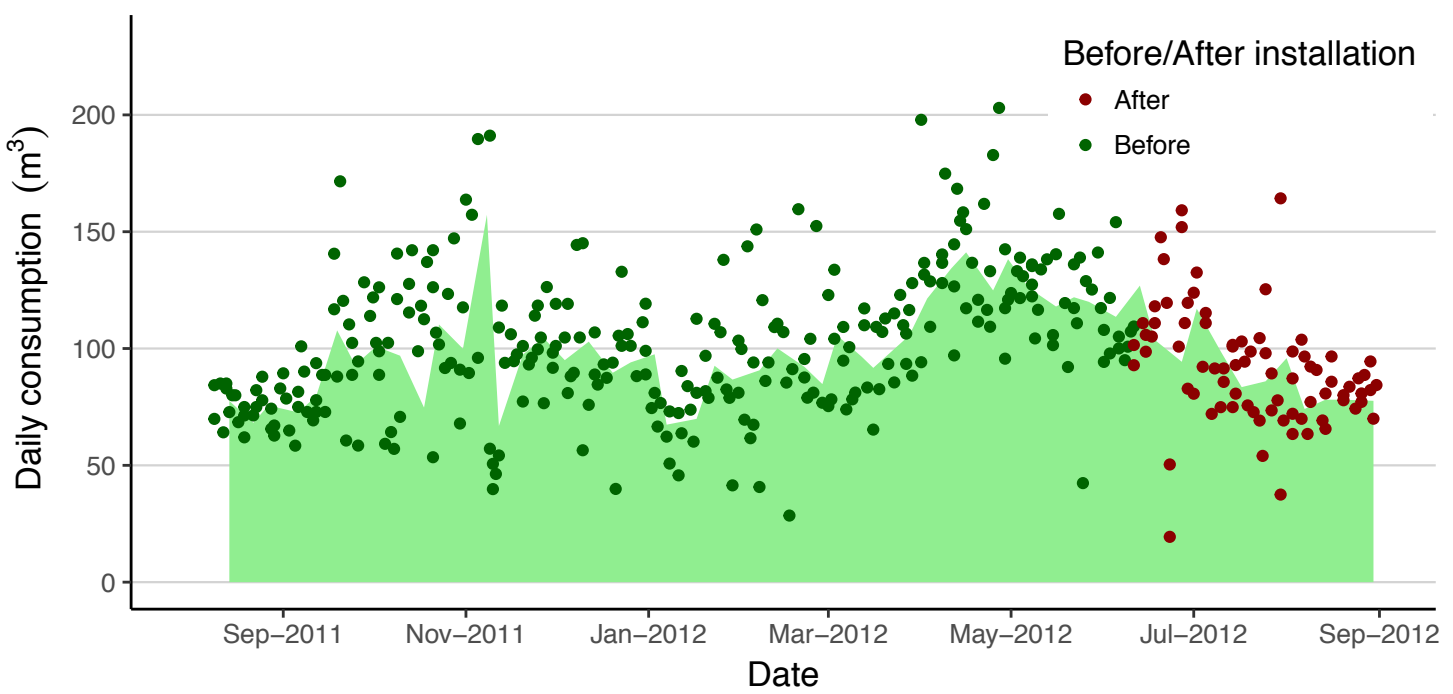

Figure 4. Daily water consumption at the Holiday Inn Hotel before and after installation of water saving devices (WSDs). The weekly average is presented in the background. 


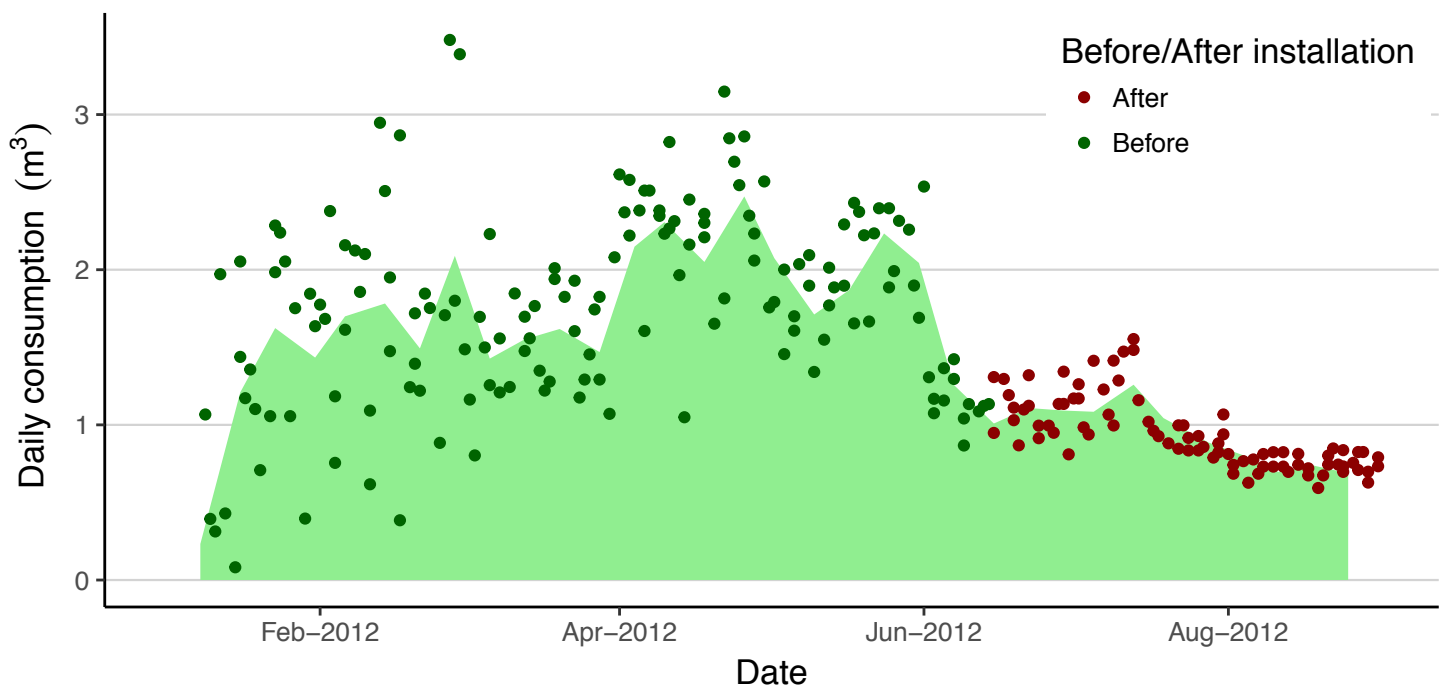

Figure 5. Daily water consumption in the Ministry of Regional Municipalities and Water Resources (MRMEWR) before and after installation of water saving devices (WSDs). The weekly average is presented in the background.

\subsection{MRMEW R Building}

The Ministry of Regional Municipalities and Water Resources building bathrooms were fitted with 24 aerators for 24 faucets and 24 sensor-activated taps. In addition, they were fitted with 24 toilet bags. Patterns of water consumption are illustrated in (Fig. 5) and (Table 2).

As expected, averages during weekdays $\left(0.92 \mathrm{~m}^{3} /\right.$ day) exceed those during weekend $\left(0.83 \mathrm{~m}^{3} /\right.$ day $)$. This is understandable considering that weekends are days of inactivity in the building. Also it was noted that water consumption increased from beginning of June to mid of July due to the summer season. Most of the staff normally takes their leave during July - September. It is worthy to note though that installation of WSDs stabilized and reduced water usage. As illustrated by the figure, water use was initially staggered but became more clustered with a clear pattern after the installation of WSDs. Descriptive statistics showed that the mean weekly consumption before installation was $12.317 \mathrm{~m}^{3}$ and decreased to $6.284 \mathrm{~m}^{3}$ after the installation of the WSDs. The calculated $t$ value ( $t$-Stat) of 4.32 was larger than critical value ( $\mathrm{t}$-Critical one tail) of 1.70 , consequently water consumption decreased significantly to about $50 \%$ following installation of WSDs.

\section{Analysis and Limitations of the Case Study Results}

The aforementioned consistent results indicate that overall WSDs are indeed significantly effective in reducing water consumption. The most powerful devices include self-closing taps, low-flow showerheads, and sensor-activated taps. Ineffective devices include aerators and toilet bags. Aerators are ineffective because most modern faucets nowadays are already equipped with aerators. Hence, installing additional aerators would not add any value in terms of significant water savings. Toilet bags are ineffective because low-flush toilets are specially designed whereby a low flush does clean the bowl. This is not the case for toilet bags installed on conventional bowls which eventually cause the toilet user to flush at least twice for effective cleaning and this may be one of the reasons for the houses inconsistent results. Also the fact that the owners of the houses may claim that they are making greater effort to conserve water although measurement of specific actions such as frequency of laundry car washing and garden watering that habits are largely unchanged.

In contrast, self-closing taps did reduce water consumption drastically in several public places and hence are recommended in mosques ablution rooms, restaurants, and schools. They are also recommended in large shopping centres despite the fact that their benefit was masked by the presence of other ineffective devices in the City Centre shopping mall. Low-flow showerheads demonstrated their benefit clearly in hotels. Sensor-activated taps are probably the most effective WSDs as they reduced water consumption significantly in the MRMEWR building. These should be installed wherever users can afford their elevated costs like banks, shopping malls and hotels.

It is strongly recommended that WSDs are used for all new public and commercial buildings in Oman, although the study shows that Omani are the lowest water consumers amongst GCC countries. It is believed that the effectiveness of water saving may increase drastically if self closing taps are used or low flow showerheads. Selection of WSD should take into account the cultural and religious values of the receiving people that was clearly reflected in the results. In discussions with household owners, a consistent pattern of answers were received 
regarding the low flush toilets, that they ended up pressing the push button either twice (in case of toilet bags) or both buttons in terms of the dual flush. Also in the selection of the self closing taps for Al-Araimi mosque, care was taken in selecting the appropriate device in terms of the time required for ablution, water flow rate and ease of use, in order not to cause any frustration to the praying person. Therefore a Wall-mounted device with a slightly higher flow and adjustable time features was chosen.

\section{Conclusion and recommendations}

The study concluded the pipe line system was the main source of water delivery to homes as indicated by $67.7 \%$ of the participants. Most people in the study area were not using any water saving methods at their homes, yet $76 \%$ considered themselves as water savers. It was indicated that there is a high awareness of water shortage in the country; $92 \%$ of participants were expecting benefits from using water saving devices in terms of money and alleviating water shortage problems. Participants were readily willing to install water saving devices in their houses.

The case studies revealed that the most effective devices in saving water were sensor-activated taps followed by self-closing taps followed by low-flow showerheads. WSDs were significantly effective in reducing water consumption in restaurants, mosques, hotels and government buildings. Water consumption in shopping centres decreased but not statically significant.

Aerators were not effective, as taps come already equipped with aerators. Toilet bags were not effective as the bowl itself must be originally designed to handle a low flush. A flush with a toilet bag was found ineffective in cleaning the bowl and thus users flushed twice thus increasing water use rather than decreasing it. A similar experience was encountered in dual flush cisterns.

This study showed that there was no significant difference in water consumption before and after installation of WSDs at homes. This was due to the fact that faucets in houses were already equipped with aerators so no savings were achieved by installing new aerators. Toilet bags and dual flush toilets were not effective and prompted users to flush twice. The low-flow showerheads were probably effective but their effect was masked by the negative effect of other WSDs.

The amount of water consumption per inhabitant ranged from $100 \mathrm{~L} /$ day.inhabitant to about $350 \mathrm{~L} /$ day.inhabitant. The higher value was due mainly to a public use of the garden water. These figures compared well with those in neighboring Gulf Council Countries.

The limitations of this study were that more than one WSD type was installed in any single establishment. The quantification of the effect of any particular WSD device alone became difficult. An important parameter that was missed, as a result, was water use per WSD. Retrofitting programs that involve replacement of existing plumbing equipment with that uses less water, and residential water audit programs that involve sending trained water auditors to participating family homes, free of charge, to encourage water conservation efforts are recommended.

It is thought that achieving water savings in the range of $20-30 \%$ as originally thought is an over-ambitious target mainly because houses will not benefit significantly from WSDs, as determined in this study. The target reduction should probably be revised to $10-15 \%$ reduction.

\section{Acknowledgements}

The authors wish to express gratitude and thanks to the Ministry of Regional Municipalities and Water resources for their great support in financing this study and providing the data to complete this paper.

\section{References}

Al-Ajmi, H. A. and Abdel Rahman, H. A. 2001. Water Management Intricacies in the Sultanate of Oman: The Augmentation-Conservation Conundrum. Water International, (Journal of the IWRA). IL, USA. 26(1): $69-79$

Al-Rumikhani, Y. 2000. An investigation of water saving devices performance and saving studies. Proceeding of WSTA 5th Gulf water conference, Doha, Vol. 1, 317-332.

Cortez M. and Petronilo 1993. Low Consumption Toilets and Other Domestic Water Saving Devices Evaluation. Proceedings of Conserve 93: The New Water Agenda, Las Vegas: 7-10.

Garcia, B. A. and Cortes, M. P., 1989. Final Report of Project UE-9003, Mexican Institute of Water Technology, Cuernavaca, Morelos, Mexico.

Garcia, O. J. 1991. Utilization of Wastewater in the Rivetex Company. Mexican Institute of Water Technology, Cuernavaca, Morelos, Mexico.

Jensen, R. 1991. Indoor water conservation. Texas Water Resources 17(4).

Lallana et al. 2001. Industrial Water Demand Management and Cleaner Production Potential : a case study of three industries in Bulawayo, Zimbabwe.

MHEW 2002. Desalination Water Production Costs. Directorate of Water, Ministry of Housing, Electricity and Water, Muscat, Sultanate of Oman.

MRMWR 2008. Water Resources in the Sultanate of Oman. Ministry of Regional Municipalities and Water Resources.

MWR 1998. The Impact of Water Savers on the Reduction of Water Consumption in Headquarters' Building. Ministry of Water Resources. 